\title{
MODEL OF ECONOMIC INTEGRATION OF THE UNIVERSITY IN THE WORLD EDUCATIONAL SPACE
}

\author{
E. V. Chuchulina
}

Perm State National Research University

\begin{abstract}
The development of the modern economy of the 21 st century and the sustainable development of cities are inextricably linked. The modern economy is a continuous process of economic integration of all subjects of economic life of society. The participation of universities in the development of cities plays a huge role. Economic integration is a factor of improvement of quality and competitiveness of the university on the world educational field. The article substantiates the importance of economic integration in the structure of the university strategy. A model of economic integration of the University was developed, also the KIU indicator of the author's methodology which was made for assessing the level of economic integration of the University, which are universal and adaptive. The methodology has been tested on the example of the Perm State National Research University (PSNRU). We conducted a correlation analysis, which showed the dependence of the level of GRP and KIU on the example of PSNRU and Perm Krai. The directly proportional relationship of the studied indicators has been proven. The authors made detailed conclusions and recommendations on the application of the model and methodology.
\end{abstract}

\section{Introduction}

Consequently, the University is the core of the economy of the region and the country as a whole. All countries have learned this truth since the formation of universities. In the era of globalization, integration and internationalization, universities will have to modernize or create from scratch a system for training modern competitive graduates on a new international level. The internationalization of the regional economy - is the integration process of economic development of the area at the international level, with the participation of international economic relations agents. As well as an agent of international economic relations the University is the main supplier of resources to the world market of educational services. Compared to other countries Russian universities are still newcomers to the world market of educational services. The first step towards integration was taken by Russian universities in the late 90 s and early 2000s, when the first international programs for the mobility of students and teachers appeared, the first educational and scientific internships, the first experience of joint learning. Quality and educational system in Russia were different from Western Models till entering into the Bologna process. The Bologna process is a system of integration and convergence of education systems (mainly higher) in Europe and other countries.

In September 2003, at the Berlin Conference of Ministers of Education of the Bologna Process Participating Countries, by that time already 33 countries, the Russian Federation, represented by the
Minister of Education of the Russian Federation V.M. Filippov, signed the Bologna Declaration, thereby Russia undertakes to implement by 2010 the basic principles of the Bologna Process [21]. Since then, Russian universities have successfully carried out the socioeconomic integration policy for the provision of educational services in the domestic and foreign markets. But not all universities are ready to face the challenges of integration, particularly in times of economic and political sanctions, pandemics, etc. New problems, new solutions. One thing is clear, no university cannot be competitive and in demand on the world market of educational services without the introduction of successful economic integration strategy, therefore, the country's economy and vital to this strategy in the region.

Within the framework of this article, the authors proceed from the fact that it is necessary to develop a methodology for assessing the level of university integration in the global economic space, since the general level of integration is one of the indicators of the region's place in the world economy. The university integration coefficient can be included in the integral indicator of assessing the level of foreign economic activity both at the regional and national levels

The purpose of this article is to form the author's approach to the definition of the concept of "university integration" and "economic integration of the university", as well as the development of the author's methodology for assessing the level of university integration in the global economic space. 
The hypothesis is based on the fact that the university is the vector of economic development of the region and the country as a whole. The level of economic integration of the university is an indicator of the GRP components at the regional level and indicators of foreign economic activity at the country level. At the present stage of economic development, the entry of universities in all regions of our country to the international level is one of the priority directions of the policy of social and economic development of the Russian Federation.

\section{Materials and Methods}

The main research method used by us is statistical and correlation analysis of data on the development of integration processes. We use the statistical database Rosstat and data from partner universities. We have developed and calculated the author's index of university integration using the example of PSNRU, and proved its correlation with the GRP of the region.

Today, many scientists are paying attention to the integration of the higher education system. The concepts of "globalization" and "integration" are satellites. One concept could not have appeared without the other. Such scientists as R. Robertson, R. Schmed, H. Kelsen, D. Schindle, I. Wallerstein, N. U. Yarychev, E. Giddens, M. Castels, W. Beck, J. Soros, K. Popper, and others made a significant contribution to the definition of "globalization" and "integration", as well as "economic integration".

Let's start with the fact that integration is "a natural process, which is a consequence of the gradual "opening "of countries to each other, during which several monostate macroeconomic organisms gradually merge into a whole polystate economic space, which is eventually structured into a new, enlarged, more efficient economic organism[20].

For consistent scientific research, we need to understand the essence and nature of the very concept of "integration".

The term "integration" comes from the Latin word "integer" - "whole". That is, integration involves the formation of some new community or a new set of separate parts, which are beginning to emerge as an independent entity [2].

Integration, as defined in the Cambridge English Dictionary, is the act or process of successfully joining or combining with another group of people[24].

Continuing the theoretical research, we will turn to the study of the prerequisites for the appearance of the term. Ernst B. Haas drew attention to the necessary prerequisites for integration, which included: the presence of common economic interests, the similarity of economic systems, interdependence, political pluralism, and the similarity of elite circles[16].

Scientists around the world often equate the concepts of "integration", "internationalization", and "globalization".

For example, N. U. Yarychev suggested that the internationalization of higher education contributes to improving its accessibility and quality, the introduction of innovative methods of work in higher education systems, and the strengthening of international cooperation [26].

Vatolkina N. Sh., Fedotkina O. P. believe that the advantages of internationalization in the field of education are: increasing the accessibility of higher education, universalizing knowledge, introducing international quality standards in education, performing joint scientific research, creating network research projects and educational programs, expanding and strengthening international cooperation [25].

Vagapov D.F. claims that "as the world experience shows, it is possible to increase the country's competitiveness through active participation in regional integration processes. Integration has a positive effect on the country's economy, as it increases the specialization and diversification of production, provides a high concentration of all types of resources and deep technological cooperation, reduces production costs (due to economies of scale) and transaction costs (reducing the amount of administrative and customs documentation [4].

Thus, integration is the process of bringing societies of people together into a circle of interests. The criteria for classifying interests can be different from political to cultural, etc. The field of higher education is no exception.

Our research is based on the economic aspects of integration processes in higher education.

Many domestic scientists, such as: Bedny A. B., Saginova O. V, Grudzinsky A. O. think that increasing the competitiveness of higher educational institutions, ensuring their effective development in a global knowledge society and fierce competition among universities around the world, it is a major challenge for all the world's leading powers. [1].

Perfilieva O. V. believes that in order to obtain a more complete picture on the status of the integration of universities in socio-economic development of the region the results of statistical analysis should be complemented by qualitative analysis of processes of interaction of universities with other actors of the socioeconomic life of the region. This area of research became a practice in many foreign countries in the early 1990s, and is on the agenda of innovation activities of the Organization for economic cooperation and development (OECD) in the field of higher education[15].

If we compare the number of foreign students in modern Russia and the USSR, Russia does not fully use its educational and economic potential to attract foreign students to study at universities, especially in the regions of our country.

It can be argued that at the present time."..Russia's presence in the international educational market does not correspond to its potential opportunities... During the Soviet Union, cadres were trained for 160 countries, and the political and business elite of a number of countries were recruited from graduates of Soviet universities... Now this system practically does not work» [17]. 
The concept of "integration" undoubtedly implies the concept of "economic integration". There are supporters and opponents of economic integration of the countries of the world, but it is impossible to deny or stop this process.

Economic integration can be beneficial for all participating countries. But after a certain point the further benefits of integration can only be achieved by exchanging the costs in one policy or sector for the benefits in another [8]. Maintaining a balance in economic integration is the task of state policy in the field of economy, education, health, etc.

Economic integration, the process by which two or more countries in a broadly defined geographic area reduce a set of trade barriers to promote or protect a set of economic goals [23].

This definition applies to the education sector. The balance in the Bologna Process is the mutual recognition of diplomas of the participating countries through the mechanisms of convergence and unification of educational programs.

Three fundamental factors have influenced the process of economic globalization and are likely to continue to stimulate it in the future. First, improvements in transport and communication technologies have reduced the cost of transporting goods, services, and factors of production, as well as the transfer of economically useful knowledge and technologies. Second, the tastes of individuals and of society as a whole, but not universally, have favored the opportunities offered by the reduced costs of transport and communications through increased economic integration. Third, public policies have significantly affected the nature and pace of economic integration, although not always in the direction of strengthening economic integration [12].

European experience shows that institutional integration interacts with economic integration at the regional level [7]. The European experience of economic integration of universities in the global education market is positive. Today, many students from all over the world come to study at European universities. Most of the universities accept students according to the uniform admission rules and the uniform requirements for English proficiency. The cost of the programs depends on the student's citizenship, for EU students, the cost is lower, while others are provided with scholarships and grants.

All this is directly reflected in the world market of educational services.

Continuing our research, let us consider the following concept of "economic integration". According to Khristinina E.G, economic integration is an objective result of the immanent aspiration of social production to the maximum positive effect based on the deepening division of labor, specialization and cooperation of production, free movement of labor and capital [18].

In accordance with the classical Western European theory, which is based on the GATT of October 30, 1947, five forms of economic integration can be distinguished:

- free trade zone;
- customs Union;

- common market (common economic space);

- economic and monetary Union;

- full integration [9].

Economic integration in the context of this study involves concessions, cooperation, and the pooling of human, economic, and political resources. It includes mutual transactions, risks, and investments that can be evaluated in terms of tangible goals and measurable results [3].

Economic integration is carried out in stages, from a lower to a higher form of economic cooperation of the countries - members of the regional formation [13].

N. N. Liventsev believes that international economic integration is "a high (Mature) degree of internationalization of production based on the development of deep stable relationships and division of labor between national farms, leading to a gradual merging of the reproductive structures of a number of countries» $[10]$.

International economic integration has achieved the greatest success on the European continent. In this regard, the main theories and practical models of regional integration in the second half of the XX century were developed and illustrated by the example of the functioning of the European Union [5].

Based on the analysis of the theoretical features of the concept of "integration", "internationalization" and "economic integration", we came to the conclusion that there is no single concept of economic integration.

In our opinion, economic integration is a continuous process of integration between countries and territories in the areas of exchange of goods, technologies, scientific inventions, human capital, finance, natural resources, information, educational systems, etc.

There are various conditions of integration of the University in the form of systems of university internationalization processes (Figure 1).

Such systems help to identify the main problematic issues that can hinder the process of integration and internationalization of the university.

At the present stage the key criteria for evaluating the integration of the University into the world educational space can be called:

- compliance with the principles of the Bologna process (for universities that have signed the Bologna Declaration);

- accreditation by international organizations, such as the Association of Commonwealth Universities (ACU), the European center for Strategic management of universities (ESNU), ASIIN, ACQUIN, etc.;

- development by universities of their own system of indicators that allow them to independently assess the existing achievements in a particular area [6].

Thus, we came to the conclusion that economic integration of the university is the process of integrating university into the global economic space with international competitive and cost-effective services that meet world educational standards and qualifications.

We turn to the development of a model of economic integration of the university. 


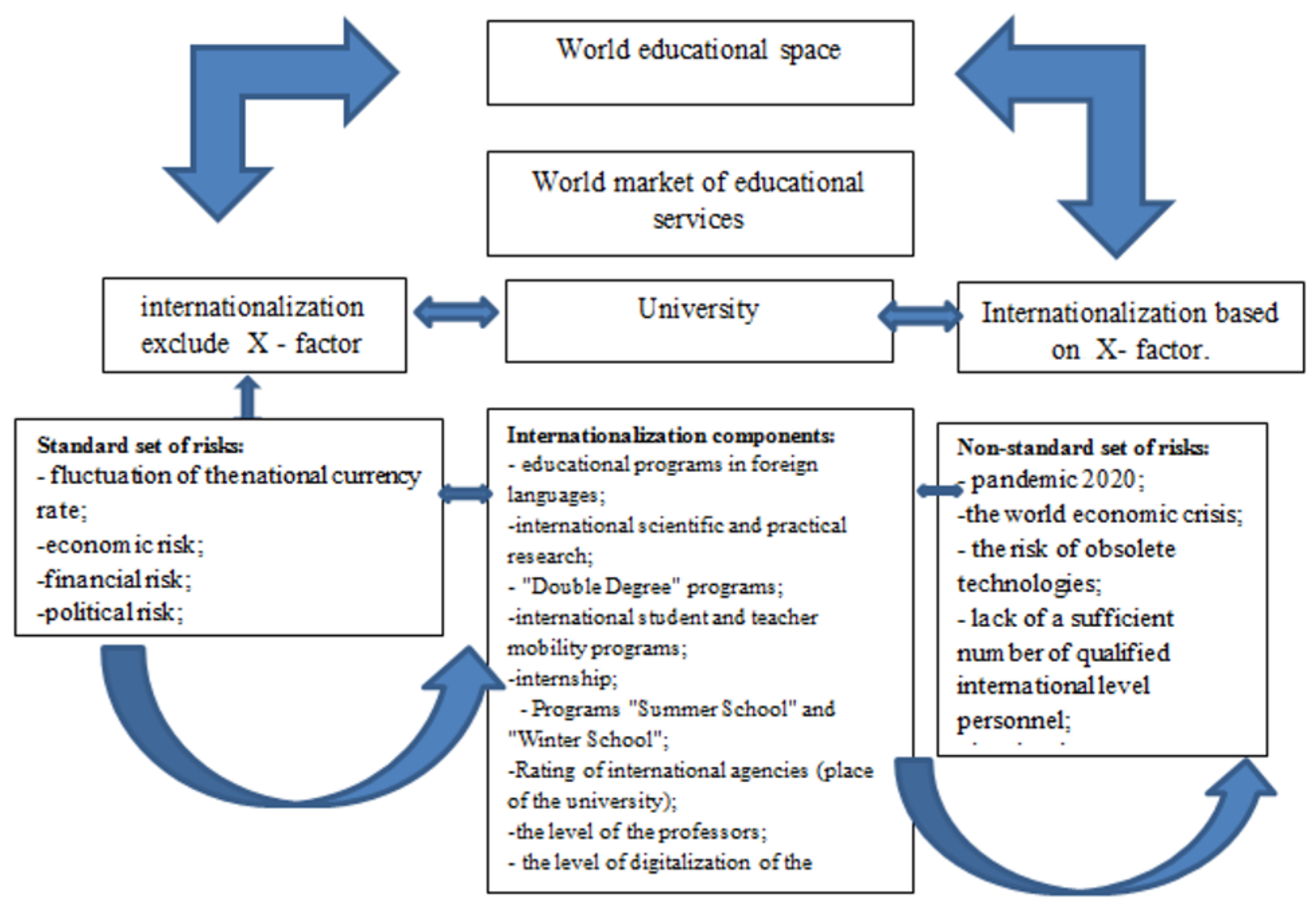

Fig. 1. The system of university internationalization processes [19].

\section{University economic integration model}

Article 1 of the Federal Law "On Education in the Russian Federation" dated December 29, 2012 No. 273FZ (last edition (as amended on July 31, 2020) states that "The objectives of the integration of education and science (research) activities in higher education are the staffing of scientific research, improve the quality of training of students on educational programs of higher education, attracting research students to be held under the guidance of scientists, the use of new knowledge and advances in science and technology in educational activities "[22]. We see that the qualitative characteristics of educational programs come out on top. To do this, it is necessary to choose the right integration strategy for the university and develop in accordance with international educational standards.

Integration of education, research and production in foreign universities was formed during the second half of the nineteenth beginning of the XXI century. For example, the American model of integration, being one of the most productive, revealing in the aspect that the graduates of such institutions more often become Nobel Prize winners. It is their pilot developments that then grow to a conveyor stream in giant technology companies that simultaneously provide scientific and technical development and multimillion-dollar profits. [14].

A modern research University is a large economic entity that has, of course, great independence. For comparison, the annual budget of the University of Texas -3 billion dollars, Standford -1 billion dollars, Manchester Metropolitan University-1 billion dollars [11].

The process of economic integration of the University occupies a major place in the formation of the economy of the region, the country and the world, as well as the world market of educational services. We will develop a model of University integration.

Stage 1. Components of economic integration of the university: staffing and human resources potential; funding sources of different levels; international educational programs in English; international partner universities ;foreign students and professors ; business partners in Russia and abroad ; Staffing and human resources potential.

At stage 1, we developed a system of components for initial indicators of the level of integration of the University into the global educational space. Human resources, in the form of employees and teachers with knowledge of foreign languages, is a resource for opening international master's, bachelor's and specialty programs in foreign languages, mainly in English. The presence of partner universities around the world is a very important indicator of integration. Foreign students 


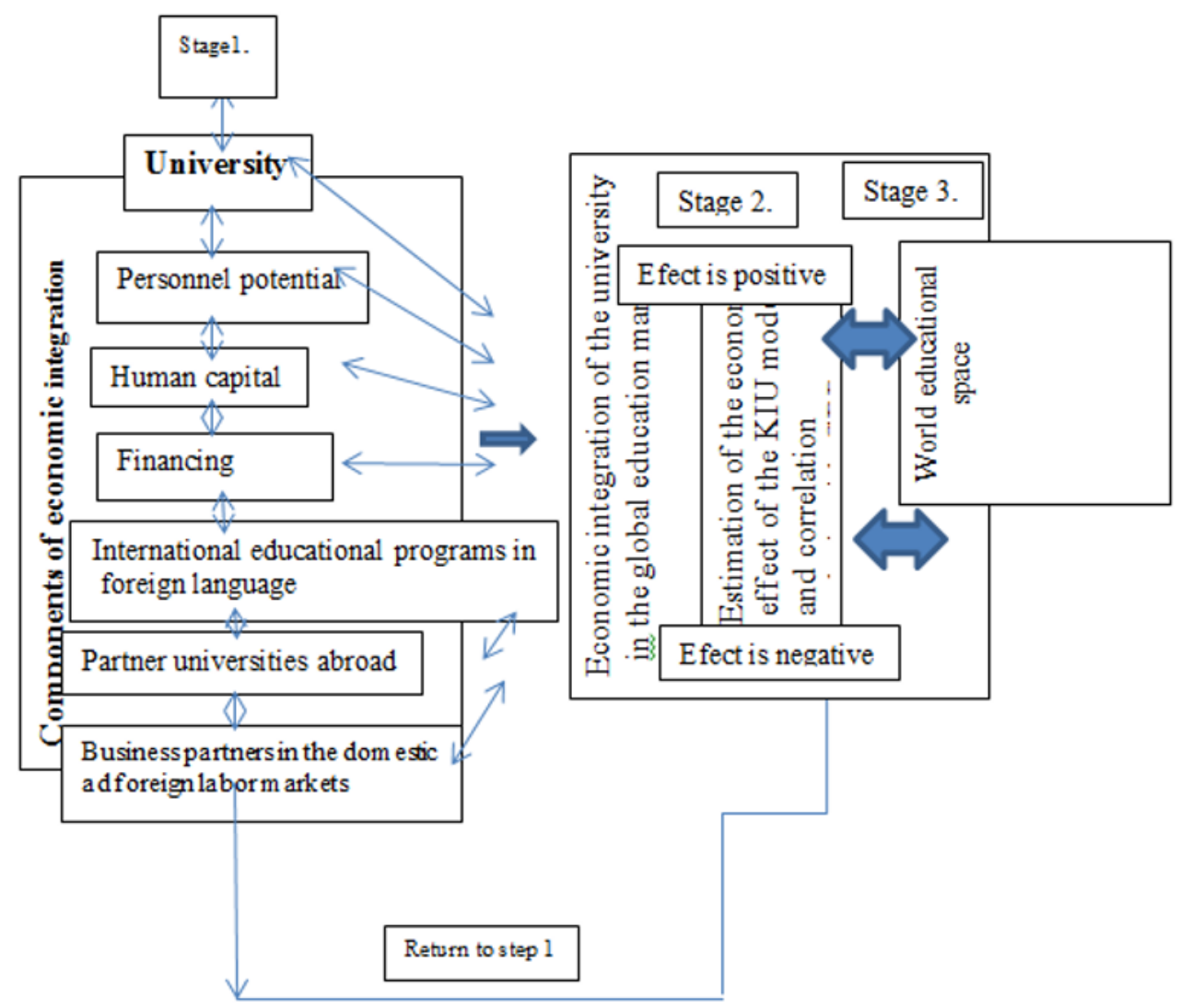

Fig. 2. Model of economic integration of the University in the world educational space.

are the main source of profit and assessment of the economic effect of university integration. Business partners are a way for the university to enter the internal and external labor markets, etc.

The components of economic integration of the University contribute to the formation of products that are in demand and popular in the world market of educational services. Economic impact assessment is the second stage of the author's model of economic integration of the University. We will develop an indicator of the author's methodology and pass the testing procedure.

Having passed stages 1 and 2, we assess the economic effect using the author's methodology and correlation analysis of the KUI indicator and GRP At stage 3 , with a positive economic effect, the university becomes a full-fledged participant in the world education market, with a negative one, we return to stage 1 and adjust management decisions to increase the level of the university's internationalization components.

\section{Results}

As a result of the research, we see the need for a detailed development of the University's economic integration methodology. Let's start by developing the first indicator of the author's methodology, which is a component of the model.
Based on the considered material and model, we propose the author's development of an indicator of the level of economic integration of the University.

$$
K I U=\frac{Q I S+Q I P+Q I P a t}{T Q S} \cdot 100 \%, \text { where }
$$

KIU - indicator of the level of economic integration of the University in the $\mathrm{j}$-th University;

QIS - number of international students at $j$-th University;

QIP - number of foreign programs (programs in English) at j-th University;

QIPat - number of foreign partner universities in $j$-th University;

TQS - total number of students in $\mathrm{j}$-th University. The indicator value is from 0 to 1 .

The indicator developed by the authors makes it possible to assess the level of economic integration of the university, reflects the number of foreign students, the level and number of programs in English for the world market of educational services, the number of foreign partner universities, which will contribute to monitoring the level of university integration, as well as making strategic management decisions. the processes of university integration from the side of the administration. The closer the indicator value is to one, the higher the level of internationalization at the university is.

Let's calculate the author's indicator using the example of PSNRU for 5 academic years, quantitative 
data are provided by PSNRU. The number of foreign students at PSNIU for the 5 years under study varied from 110 to 157 ; the number of foreign programs (programs in English) from 1 - 4; the number of foreign partner universities of PSNRU is from 30 to 33; the total number of PSNIU students from 11,500 to 12,200 people.

The KIU indicator of Perm State National Research University has been steadily increasing from 2014 to 2019, therefore, we are observing a positive trend. From the analyzed data provided by PSNRU, there is a positive trend in the growth of the number of foreign students and educational programs in English. Programs in English are one of the main indicators of the economic integration of a university with a proven economic effect.

\section{Discussion}

To assess the economic effect of the KIU indicator, relying on the data of the official statistics and statistics of the PSNRU, we calculate the correlation coefficients between the KIU indicator of the PSNRU and the GRP in the Perm Krai in dynamics over the years.

Table 1. Indicator KIU and GRP in the Perm Krai.

\begin{tabular}{|c|c|c|}
\hline Year & KUI & $\begin{array}{c}\text { GRP (per capita in the Perm Krai, } \\
\text { in current prices RUB) [21]. }\end{array}$ \\
\hline $2014 / 2015$ & 1,1 & 369489,3 \\
\hline $2015 / 2016$ & 1,2 & 403601,4 \\
\hline $2016 / 2017$ & 1,3 & 416203,6 \\
\hline $2017 / 2018$ & 1,5 & 453431,5 \\
\hline $2018 / 2019$ & 1,6 & 503818,3 \\
\hline
\end{tabular}

Thus, a correlation coefficient greater from 0 to 1 indicates a directly proportional relationship, and a coefficient from -1 to 0 is inversely proportional. In our calculations, we revealed a directly proportional relationship between the level of university integration and GRP.

As a dependent factor, we will use KUI - an indicator of the level of university integration, and as independent factors - GRP per capita in the Perm $r$ Krai. To calculate the correlation coefficient, we will use the Excel program (tab. 1). We obtained a statistical relationship between the investigated factors. The correlation coefficient was 0.94 , which means that there is a close relationship between the KIU level and the region's GRP. Correlation analysis helped us to solve the following problems:

1. Establish a relationship. Our research has found that there is a close correlation between KUI - an indicator of the level of integration between the university and GRP;

2. Forecasting. If we know the behavior of one parameter, then we can make a prediction of the behavior of another research parameter that correlates with the first.

3. Classification and identification. Correlation analysis helps to select a set of independent features for classification.
This indicator of the author's methodology is adaptive and can be used to calculate the overall level of integration of universities in the country.

\section{Conclusion}

In an era of new challenges facing the higher education system, today, more than ever, it is necessary to explore and develop new ways and forms of economic integration of universities. As shows our research of theoretical and practical hypotheses, universities in Russia's regions have potential to implement strategy of economic integration into the global educational space, but they are not always able to fully implement it. To realize the potential, it is necessary to approbate the model of economic integration of the university, which is adaptive and universal. The author's indicator of the methodology was tested on the example of PSNRU, and it is necessary to continue developing the methodology of economic integration of the University for testing in the regions of the Russian Federation. According to the developed methodology, it is possible to identify the weak and strong points in the organization of the international activities of the university, it becomes possible to assess the degree of equipment of the university with tools for implementing a successful strategy of economic integration into the world educational space. According to the results of the study, PSNRU is classified as a university with a high level of economic integration, but the potential is not fully realized, which requires the development of an algorithm for making managerial decisions to implement and improve the economic model. It is necessary to pay attention to the universality and adaptability of the models and methods for assessing the economic integration of the university proposed by the authors; it is easy to apply in practice in the regions of the Russian Federation.

Finaly, we came to the conclusion that it is necessary to develop and supplement a methodology for assessing the level of university integration into the global economic space, KIU will be one of the indicators with a proven economic effect, it is a kind of initial indicator and incentive for making and adjusting management decisions in the strategic development of the university governing bodies.

\section{References}

1. Poor A. B., Grudzinsky A. O. Internationalization as a driver of development // Management of international activities of the university. - 2014. P.114-119. [Electronic resource]. URL: http: // file: ///

$\mathrm{C}$ : /Users/ASUS/Desktop/Scopus\%202019/zhunaly\%2 OScopus/UroRAN/internatsionalizatsiya-kakdrayver-innovatsionnogo-razvitiya-universiteta.pdf (date of access 26.11.2020)

2. O.V. Butorina The concept of regional integration: new approaches // analytical portal Polit.ru. - 2006-. [Electronic resource]. URL: // 
http://polit.ru/article/2006/04/10/butorina/ (date of treatment 25.11.2020).

3. Byrne, A. V; Matic, M; \& Fissuh, E. (2009). Awareness \& process: The role of the European Union Peace II Fund \& the international fund for Ireland in buildingthe peace dividend in Northern Ireland // Journal of conflict studies / - 2007- / Vol. 27 No. 1. [Electronic resource]. URL: https://pdxscholar.library.pdx.edu/cgi/viewcontent.c gi $?$ article $=2893 \&$ context $=$ open_access_etds (accessed 26.11.2020).

4. Vagapov D.F. Changing the concept of Russia's participation in regional integration processes in the light of national economic interests // Strategy of economic development / - 2009 / - 12 (45). - C 3747.

5. Voronina T.V., Evolution of theoretical approaches to the analysis of the development of international economic integration // Terra economicus. - 2010. Volume: 8Number: 3-3. - pp. 208-215.

6. Denisov A.R., Stepanova M.M. Development of a system of indicators of the level of internationalization of the university // Education and Science. - 2015. - No. 9 (128). - S. 15-32.

7. Dorrucci T. Ettore, Firpo Stefano, Fratzscher \& Francesco Marcel, Mongelli Paolo. The Link between Institutional and Economic Integration: Insights for Latin America from the European Experience // Open Economies Review. -2004. Volume 15. -P. 239-260. [Electronic resource]. URL: http:

https://link.springer.com/article/10.1023/B:OPEN.0 000037699.34047.be (access date 29.11.2020).

8. Hornik J., Nicolaides Phedon A. The Political Limits of Economic Integration // Volume. 52, 2017 - Number 5 - pp. 315-322.

9. Kurbanov R. A. Economic integration: concept, theory and types // Business in law - 2015. - №2. FROM. 107-111.

10. Liventseva N.N. International economic integration: textbook. allowance - M .: Economist, -2006. -C.7.

11. Mohrman K., MaW.H., Baker D. The research university in transition: thee merging global model // Higher EducationPolicy. - 2010. -№12-. pp.5-27.

12. Mussa M. Factors Driving Global Economic Integration // Economic Counselor and Director of Research, IMF. Economic Counselor and Director of Research IMF Presented in Jackson Hole, Wyomingat a symposium sponsored by the Federal Reserve Bank of Kansas City on "Global Opportunities and Challenges," August 25, 2000. [Electronic resource]. URL: https://www.imf.org/en/News/Articles/2015/09/28/0 4/53/sp082500 (date accessed 27.11.2020).

13. Joram Mukama Biswaro. The Quest for Regional Integration in Africa, Latin America and Beyond in the Twenty First Century: Experience, Progress and Prospects // Fundação Alexandre de Gusmão Brasilia. -2011. - P. 458.
14. Neborskiy E.V. Models of integration of education, science and business in the universities of the USA, Europe and Japan // Problems of modern education [Electronic resource]. URL: http: // www.pmedu.ru 2011, No. 1.48-59 (date of treatment 29.11.2020).

15. Perfilieva O.V. The role of universities in regional development. Methodology for assessing the socioeconomic effects of implementing a project to create federal universities in the interests of regions, industries, education systems // Bulletin of international organizations. -No. 3. -2010. -P.12.

16. Pursiainen K. Theories of integration and the framework of EU - RF relations [Electronic resource]. URL: http: //www.recep.rufilesdocuments. -FROM. 3-10. (date of treatment 30.11.2020)

17. Poletaev D.V., Dementyeva S.V. Innovative strategies for the development of international education from the perspective of educational migration to Russian universities // Bulletin of the Tomsk Polytechnic University. - T. 316 No. 6. 2010 .

18. Khristinina E.G. Integration as a factor in the formation of the competitiveness of the economic system of Russia // Abstract of the dissertation for the degree of candidate of economic sciences, Saratov. -2009 .

19. Chuchulina E.V. The process of university internationalization during the global economic crisis // Trends in the development of science and education. - 65-2. - 2020. -S.39-44.

20. Shishkov Yu.V. Formation of the European Economic Space // Looking into the 21st century: EU and CIS. M., - 1998. -S.83.

21. [Electronic resource]. URL: http://bologna.spbu.ru/ (date of treatment 30.11.2020).

22. [Electronic resource]. URL: https://permstat.gks.ru/storage/mediabank/

MANUFACTURING\% $20 \quad$ GROSS $\% \quad 20$ REGIONAL\% 20 PRODUCT.pdf (date of access 30.11.2020).

23. Article 72. Forms of integration of educational and scientific (research) activities in higher education. Federal Law "On Education in the Russian Federation" dated December 29, 2012 N 273-FZ (last edition (as amended on July 31, 2020). [Electronic resource]. Https://legalacts.ru/doc/273_FZ-ob-obrazovanii/ (date of treatment 27.112020)

24. [Electronic resource].

URL: https://www.britannica.com/topic/economicintegration. (date of treatment 3.11.2020).

25. [Electronic resource]. URL: https://dictionary.cambridge.org/ru/dictionaries/engl ish/integration (date accessed 30.11.2020).

26. [Electronic resource]. URL: https://www.elibrary.ru/item.asp?id=24053996 (date of treatment 29.11.2020). 


\section{7. [Electronic resource].}

URL:

http://journalpro.ru/articles/razvitie-

internatsionalizatsii-vysshego-obrazovaniya-

rossiyskikh-vuzov/ (date of treatment 28.11.2020). 